\title{
ДИДАКТИКО-МЕТОДОЛОГИЧЕСКИЕ ОСНОВАНИЯ ОБУЧЕНИЯ РУССКОМУ ЯЗЫКУ СТУДЕНТОВ ВУЗОВ КИТАЯ
}

\section{DIDACTIC-METHODOLOGICAL FOUNDATIONS FOR TEACHING THE RUSSIAN LANGUAGE FOR STUDENTS OF UNIVERSITIES OF CHINA}

Li Na

Summary: The article actualizes the problems of teaching Russian to students of Chinese universities. The author considers this problem from the standpoint of taking into account the didactic and methodological foundations of the learning process. The article presents the arguments of the didactic-methodological synthesis of traditional and modern, as well as innovative pedagogical concepts and approaches to the process of learning Russian by Chinese students. The author analyzes the specifics of traditions in the education system of China, emphasizes its important aspects for the solid mastering of language material, as well as the organic synthesis with modern methodological approaches, for the realization of which the skills acquired by students using traditional approaches are a fundamental linguistic base in preparation for their professional activities in the context of international cooperation and economic cooperation among the countries and regions. The article presents examples of the use of traditional, modern and innovative methodological approaches, and also shows their didactic potential. The author substantiates the effectiveness of didactic-methodological synthesis from the standpoint of cultural, historical, national-ethnological, articulation-morphological and ideological features of Chinese students.

Keywords: students of higher educational institutions of China, teaching Russian, cultural, historical and national-ethnic features, didactic and methodological foundations, traditional didactic concepts, modern and innovative didactic and methodological approaches.

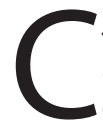

ложившаяся в настоящее время ситуация тесного международного взаимодействия и сотрудничества, границы которой имеют стабильную тенденцию к расширению в условиях глобализационных трансформаций, обусловила специфику взаимодействия стран России и Китая. В рамках этого взаимодействия, благодаря которому происходит быстрое развитие промышленно-эконмических зон, а также совместных научных исследований, становится предопределенным процесс устранения языковых барьеров, позволяющих сделать международное сотрудничество двух стран эффективным и прогрессивным.

Изучение русского языка в образовательных учреждениях Китая входит в план реализации многих образовательных программ, подразумевающих осуществление

\author{
Ли $\mathrm{Ha}$ \\ старший преподаватель, Сианьский нефтяной \\ университет, Сиань, КНP \\ Na.Li.lecturer@yandex.ru
}

Аннотация: В статье актуализируется проблематика обучения русскому языку студентов вузов Китая. Автор рассматривает данную проблему с позиций учета дидактико-методологических оснований процесса обучения. В статье представлены аргументы дидактико-методологического синтеза традиционных и современных, а также инновационных педагогический концепций и подходов к процессу изучению русского языка китайскими студентами. Автором анализируется специфика традиций в системе образования Китая, подчеркиваются важные ее стороны для прочного усвоения языкового материала, а также органичность синтеза с современными методологическими подходами, для реализации которых навыки, приобретенные студентами при использовании традиционных подходов, являются фундаментальной лингвистической базой в рамках подготовки к профессиональной деятельности в условиях международного сотрудничества и экономического взаимодействия содружествующих стран и регионов. В статье приведены примеры использования традиционных, современных и инновационных методологических подходов, а также показан их дидактический потенциал. Автор обосновывает эффективность дидактико-методологического синтеза с позиций учета культурно-исторических, национально-этнологических, артикуляционно-морфологических и идеологических особенностей китайских студентов.

Ключевые слова: студенты вузов Китая, обучение русскому языку, культурноисторические и национально-этнические особенности, дидактико-методологические основания, традиционные дидактические концепции, современные и инновационные дидактико-методологические подходы.

дальнейших процессов преемственности образования китайских студентов в отечественных, российских вузах, а также входящих в рамки обменных программ, программ академической мобильности, обмена кадрами и мн. др.

Данная ситуация подтверждает эскалацию роли изучения русского языка студентами вузов Китая и в настоящее время начинает достаточно широко освещаться в контексте научных исследований. Так, например, значение языковой подготовки иностранных студентов-граждан Китая на этапе довузовского обучения показано в работах А.Ю. Артемьева, О.Ю. Рождественской, К.С. Савина и др. $[1 ; 6 ; 7]$.

Особенности обучения русскому языку, а также труд- 
ности, которые необходимо учитывать при обучении китайских студентов, подробно изложены в трудах А.С. Разиной, Е.А. Вакула, В.В. Колесниковой, Я. Тань и др. [2; 5; 8].

Возможности и перспективы успешного изучения русского языка студентами Китая подробно изучены Фэн Шисуюань, Нгуен Фыонг Нгок, Н.В. Поморцевой и др. [3; $4 ; 9]$.

Постоянно расширяющийся спектр научных исследований в рамках данной проблематики говорит о нарастающей ее актуальности, что и определило цель нашей работы, состоящей в выявлении дидактико-методологических оснований обучения русскому языку студентов вузов Китая.

Анализируя спектр практической методологии и дидактических концепций, которые могут повлиять на процесс обучения русскому языку китайских граждан, обучающихся в вузах, необходимо отметить, что ее специфика должна всецело учитывать культурно-исторические, национально-этнологические особенности китайских студентов, а также, что достаточно немаловажно, ключевые аспекты системы образования Китая, который положен в основу функционирования образовательных учреждений страны. Знание этой специфики и ее учет при выборе дидактико-методологических основ обучения будет способствовать наиболее эффективному усвоению русского языка студентами вузов Китая и результативному его использованию в рамках коммуникативного взаимодействия [7].

Говоря о системе образования Китая, исторически обусловленной программой повышения уровня образованности населения, в рамках экстраполяции ее на базис существующих дидактико-методологических оснований, дидактических теорий и концепций, необходимо отметить, что китайская система образования является достаточно уникальной и практически равнокомпонентно сочетает в себе традиционные и инновационные подходы. Такое сочетание методологических основ является очень удачным и для освоения китайскими студентами русского языка, который представляет для них определенные трудности, связанные и функционированием артикуляционного аппарата, дыхательной системы, а также проявляющиеся в рамках языковой сопоставимости $[6 ; 8 ; 9]$.

\section{Рассмотрим это более подробно.}

Так, например, исторически известно, что в систему образования Китая положен так называемый схоластический принцип, предопределяющий концепцию многократного повторения изучаемого материала для прочного его усвоения. Это связано с тем, что образование в Китае выполняет роль особой высокой привилегии, что побуждает обучающихся к проявлению упорства и трудолюбия. В связи с этим данная особенность системы образования в КНР может быть успешно экстраполирована на методологических потенциал традиционных дидактико-методологических оснований, принципиальным инструментарием которых принято рассматривать такие концепты как «правило», «упражнение», «руководство» и «управление».

Концепт «правило» в рамках изучения русского языка китайскими студентами используется с самого начального этапа языковой подготовки и опосредует изучение фонетического, морфологического, грамматического строя языка, что связано с преодолением ряда специфических трудностей: например, дифференциация некоторых гласных звуков достигается китайскими студентами многократных прослушиванием и повторением; усвоение лексем опосредовано систематическим подходом к заучиванию; изучение грамматического строя языка реализуется на исторически основанном использовании грамматико-переводной методики и т.п.

В этом же контексте традиционной методологии используется и концепт «упражнение», предопределяющий, например, тренировку артикуляционно-дыхательного аппарата, поскольку изучение русского языка студентами вузов Китая связано с формированием совершенно новых для них речедвигательных навыков и дыхательных функций при говорении. Помимо этого, направленность системы образования Китая исторически сформировала такой подход в обучении как систематическая тренировка памяти, направленная на усвоение больших объемов учебного материала, в связи с чем усвоение лексического потенциала русского языка эффективно выстраивать по этому же принципу: китайцы обладают хорошими мнемическими способностями и способны усвоить обширную часть лексики посредством репродуктивных методов, определяемых традиционными дидактико-методологическим основаниями.

Также необходимо отметить, что педагог для студентов вузов Китая, априори является личностью, вера в которую безгранична и обусловлена высоким уважением к его знаниям. Воспринимаемый как носитель истинного знания, преподаватель русского языка должен на начальном этапе работы с аудиторией ориентироваться на педагогоцентрическую дидактическую концепцию, положенную в реализацию концептов «руководство» и «управление» и лишь, спустя некоторое время, постепенно переходить к использованию инструментария современных дидактико-методологических подходов (так как метод контрастов или деловых игр).

Таким образом, широкое использование традиционных дидактико-методологических оснований при обучении студентов вузов Китая русскому языку основано 
на эффективности традиционной классической триады «усвоение-закрепление-систематическое повторение», заложенной спецификой национальной системы образования.

Использование в процессе обучения русскому языку китайских студентов на основе современных дидактикометодологических подходов также имеет место.

Так, например, зная, что новыми структурно-компонентными элементами современных дидактико-методологических оснований и соответствующих дидактических теорий и концепций является такие элементы как проблемное обучение, педагогика сотрудничества, развивающее обучение, программированное обучение и т.д., преподаватели русского языка в китайских вузах ориентированы на следующие возможности повышение эффективности языковой подготовки:

- предварительное ознакомление с действием, а также с условиями его выполнения (например, дифференциация в словах звуков [ы] и [и] с последующим их произношением);

- формирование данного действия с развертывание всех входящих в его границы операций (например, прослушивание, узнавание, сопоставление с похожими звуками родного языка, просмотр изображения артикуляции с повторением, настраивание дыхания, произнесение отдельно, произнесение в составе лексемы, повторение с максимальным соответствием);

- формирование самого действия по внутренней речи (например, формирование алгоритма дифференциации и произнесения звуков [ы] и [и]);

- перевод изучаемого действия в глубокие свернутые процессы мышления (осмысление процесса на основе возникающих ассоциаций; оценка работы артикуляционного аппарата; осознание того, что получилось, а что нет; понимание трудности и путей ее преодоления; самооценка; рефлексия).

Таким образом, на этапе согласованного использования традиционных и современных дидактико-методологических подходов происходит своеобразная реализация потенциала современных теорий обучения, обеспечивающая эффективность не только усвоения базовых основ русского языка, но и так называемого аккуратного перевода в сознании китайских студентов культурно-мировоззренческих аспектов процесса обучения на основу применения инноваций, которые, с первого взгляда, противоречат традиционной национальной идеологии.

Так, например, в рамках данного методологического синтеза достаточно продуктивной будет реализация деятельностного подхода, предполагающая уже не только педагогоцентрический, но и самостоятельный творческий аспекты деятельности китайских студентов в рамках освоения русского языка. С этой позиции для студентов также важны и основания ассоциативно-рефлекторной педагогической концепции, которая базируется на установлении взаимосвязей наглядно-объяснительного обучения, что необходимо на начальных этапах языковой подготовки. Позже, автоматизированные языковые навыки могут быть реализованы в ходе самосовершенствования в самостоятельной деятельности студентов. В контексте такой методологии могут быть освоены навыки эмотивно-эмпатийной и организационно-регулятивной коммуникации, в рамках которых китайские студенты учатся представлять себя на русском языке, показывать уровень языковых знаний, умений и навыков в монологической и диалогической речи, а также при коммуникативном взаимодействии в группе (причем в состав которой могут входить и представители-носители языка), т.е. показывать владение различными видами речевой деятельности.

На этапе осознания концептуальных оснований современных дидактико-методологических подходов (самостоятельность при обучении, использование виртуальных ресурсов, диалог и сотрудничество с преподавателем и пр.) при обучении китайских студентов русскому языку целесообразным и эффективным становится применение инновационных дидактико-методологического инструментария, направленного уже на углубленный языковой анализ, составление языкового портфеля для успешной будущей профессиональной деятельности. В этой связи совокупность методологических подходов уже будет включать в себя и такие технологии как развитие критического мышления, позволяющего усовершенствовать читательскую стратегию студентов и навыки разговорной (обыденной и деловой) речи; методы контрастов, при которых педагог целенаправленно допускает ошибку, и студенты понимают, что это специфика обучения, ориентирующая их на критический анализ и поиск аргументов; метод деловых игр, позволяющий сотрудничать с педагогом на равных при решении творческих профессиональных задач на русском языке и пр.

Необходимо также отметить, что очень важное значение для китайских студентов имеет заинтересованность педагогом: педагог, преподающий русский язык в вузе Китая и использующий методы традиционной и инновационной направленности выступает в роли высоко мотивирующего фактора к изучению языка, так как на основе традиционной методологии, которая предписана системой образования Китая и к которой привыкли китайские обучающиеся, педагог, умело сочетающий концепт «знаниевой» парадигмы помогает студентам разобраться в трудностях языка, привлекая и интересные методы, связанные с инновациями, что выражается в продуктивном решении следующих дидактико-мето- 
дологических задач:

- формирование способности китайских студентов распознавать и конструировать структуру, адекватную русскоязычному замыслу (при анализе текста, речи говорящего, а также в диалогический или монологической речи и т.д.);

- оформлять и структурировать лексические единицы выбранной структуры в соответствии с нормами и правилами русского языка, спецификой грамматических конструкций, употребляемых во временном аспекте;

- осуществлять эффективный самоанализ и рефлексию в сопоставлении с правилами употребления и правильности выражения собственного замысла;

- использовать функционал языка применительно к профессиональной деятельности, которую предстоит осуществлять;

- совершенствовать языковые навыки посред- ством увеличения скорости связи лексем в грамматических конструкциях при сохранении смысла и адекватности структуры.

Таким образом, специфика дидактико-методологического синтеза, заключающаяся в сочетании традиционных и инновационных методологических подходов при обучении русскому языку студентов вузов Китая, прогрессивно отражается на освоении ими [студентами] всех разделов языка. Традиционные дидактические концепции, экстраполированные на современные технологии (развития критического мышления через чтение и письмо, электронного портфолио, проектные и т.п.) позволяют добиться высокой эффективности в развитии иноязычной познавательной деятельности студентов вузов Китая на основе учета культурно-исторической, национально-этнологической, артикуляционно-морфологической и идеологической специфики.

\section{ЛИТЕРАТУРА}

1. Артемьев А.Ю. Место факультетов довузовской подготовки для иностранных граждан в системе подготовки специалистов для зарубежных стран российскими высшими учебными заведениями [Электронный ресурс] / А.Ю. Артемьев. - Режим доступа: https://lib.herzen.spb.ru/media/magazines/

2. Вакула Е.А. Особенности преподавания русского языка как иностранного китайским слушателям на начальном этапе обучения [Электронный ресурс] / Е.А. Вакула, В.В. Колесникова, Е.Ю. Можаева // Современные проблемы науки и образования. - 2018. - № 4. - Режим доступа: https://science-education. $\mathrm{ru} / \mathrm{ru} /$ article/view?id $=27790$

3. Нгуен Фыонг Нгок. Актуальные проблемы при изучении русского языка иностранными студентами / Фыонг Нгок Нгуен, Ван Зы Чан // Актуальные вопросы современной филологии и журналистики. - 2012. - № 8. - С. 44-48.

4. Поморцева Н.В. Культуроориентированные интегрированные технологии в процессе преподавания русского языка как иностранного / Н.В. Поморцева // Вестник Российского университета дружбы народов. Серия: Русский и иностранные языки и методика их преподавания. - 2007. - № 2. - С. 13-18.

5. Разин, А.С. Способы улучшения произношения у китайских студентов при изучении русского языка / А.С. Разина // Молодой ученый. - 2018. - №21. C. $212-215$.

6. Рождественская 0.Ю. Как научить общаться на начальном этапе обучения русскому языку: Сборник материалов Недели русского языка и российской культуры. Италия, Милан - Бари - Рим / 0.Ю. Рождественская. - Москва, 2012. - С. 51-56.

7. Савин К.С. Проблемы и пути решения вопросов преподавания русского языка как иностранного в процессе изучения экономических дисциплин / К.С. Савин // Балтийский Гуманитарный журнал. - 2017. - Том 6. - № 2 (19). - С. 179-180.

8. Тань Я. Этнопсихологические особенности обучения китайских учащихся / Я. Тань // Молодой ученый. - 2017. - № 17. - С. 288-291.

9. Шисюань Фэн. Изучение русского языка китайскими студентами: проблемы, возможности, перспективы / Фэн Шисюань // Русистика. - 2015. - № 2. C. 70-74. 